\title{
KAJIAN ETNOMATEMATIKA ANGKLUNG PAGLAK BANYUWANGI
}

\author{
Nur Hidayatulloh ${ }^{1}$, Rachmaniah Mirza Hariastuti \\ ${ }^{1,2}$ Pendidikan Matematika, Universitas PGRI Banyuwangi \\ E-mail: $\quad$ nurhidayatulloh648@gmail.com ${ }^{1)}$ \\ mirzarachmania@gmail.com ${ }^{2)}$
}

Received 12 September 2018; Received in revised form 5 November 2018; Accepted 20 December 2018

\begin{abstract}
Angklung Paglak is a typical Banyuwangi angklung musical instrument that is heard from above using the tone of the Banyuwangian genre. Angklung Paglak has many things that can be explored to be used with mathematical concepts. The purpose of this study is to find out mathematics concept in angklung paglak Banyuwangi This research is exploratory-descriptive research. Data collection is done by literature review, observation, interviews and documentation. Data were analyzed by qualitative methods. The results of this study indicate that: (1) The characteristics of angklung paglak Banyuwangi in terms of shape and process are the same as the other Banyuwangi angklung types. Angklung paglak and other Banyuwangi angklung have differences in terms of many players. Paglak angklung players were 4 people, 2 angklung players and 2 drums players while the other Banyuwangi angklung players varied. (2) The mathematical concept in angklung paglak is about two or three-dimensional geometric shapes; traditional measurement units; concept of equating length to an object; and concept of equating length to an object.
\end{abstract}

Keywords: Angklung Paglak Banyuwangi; Ethnomathematic; Mathematical Concept.

\section{PENDAHULUAN}

Banyuwangi adalah salah satu kabupaten terluas di Provinsi Jawa Timur, yang meliputi 24 kecamatan dan berbatasan langsung dengan Provinsi tujuan wisata yaitu Pulau Bali (Suharti, 2012:24). Letak geografis yang berada dekat dengan laut merupakan salah satu faktor bertemunya macam-macam etnis di Banyuwangi seperti etnis Jawa, etnis Madura, etnis Osing, etnis Arab, dan etnis Bali. Hampir semua etnis khususnya etnis Osing sangat peduli terhadap budaya dan keseniannya. Seni dianggap sebagai salah satu warisan nenek moyang yang perlu dilestarikan secara turun-temurun dari generasi ke generasi tanpa mengubah nilai dan norma-norma atau adat istiadat yang sudah ada. Contoh kesenian Osing yang masih dilestarikan yaitu kesenian angklung.

Kesenian angklung memiliki kaitan yang erat dengan adat istiadat, seni, dan identitas budaya di Indonesia yang biasa dimainkan selama upacara seperti penanaman padi, panen, dan sunat (Tedjasendjaja \& Dharmadi, 2015:109). Kesenian angklung merupakan salah satu kesenian yang masih berkembang dengan baik di Banyuwangi. Seni angklung tumbuh di Banyuwangi dari tradisi masyarakat agraris, yaitu menggunakan bunyi kotekan dari bambu yang pada awalnya dimaksudkan untuk mengusir burung di sawah ketika musim padi (Sutarto, 2006:8). Berdasarkan bahan, bentuk, dan permainan yang dilakukan secara umum angklung dapat menjadi obyek penelitian yang menarik dari segi budaya maupun dari segi lain.

Penelitian tentang angklung yang dilakukan oleh Komariyah (2016:13) memberikan kesimpulan bahwa musik angklung dapat meningkatkan kualitas hidup wanita lansia pada domain fisik, psikologis, hubungan sosial, dan lingkungan. Sedangkan penelitian yang dilakukan oleh Rohmatun dkk 
(2017:540) menunjukkan bahwa melalui penerapan media musik angklung dapat meningkatkan apresiasi seni siswa kelas 5 siswa pada mata pelajaran seni, budaya. Terdapat beberapa jenis angklung di Banyuwangi, diantaranya: angklung caruk, angklung tetak, angklung dwi laras, angklung Blambangan dan angklung paglak.

Penelitian ini difokuskan pada eksplorasi kesenian angklung paglak. Angklung paglak merupakan angklung yang dibunyikan dari atas pondok kecil ditengah sawah (Syaiful, 2015:37). Lebih lanjut dikatakan bahwa paglak itu sendiri dalam kamus Osing-Indonesia berarti pondok kecil di tengah sawah yang lantainya dibuat diketinggian.

Pada jaman dahulu, angklung paglak dibunyikan pada saat panen tiba. Paglak dibuat di tengah sawah dengan ketinggian hingga sepuluh meter dari tanah. Hal ini dilakukan untuk menghibur orang-orang yang sedang bekerja disawah saat panen tiba yang bukan hanya dimainkan pada saat panen saja tetapi juga dibunyikan pada saat kegiatan-kegiatan penting lain seperti upacara adat dan penyambutan tamu (Syaiful, 2015:35). Angklung paglak menjadi obyek penelitian yang menarik untuk dieksplorasi karena keunikan permainan yang dilakukan di atas pondok kecil di tengah sawah

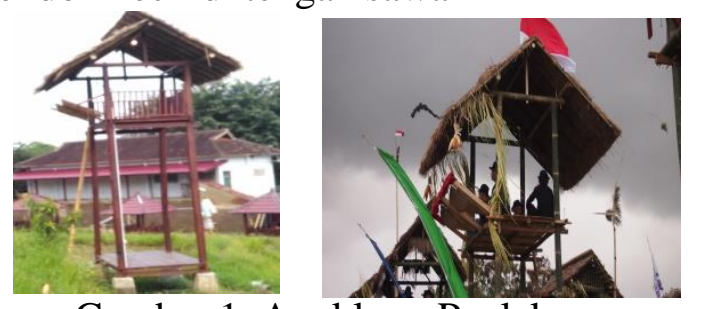

Gambar 1. Angklung Paglak Banyuwangi

Angklung paglak Banyuwangi dimainkan satu hari penuh sejak pukul 08.00 WIB hingga petang sekitar pukul 15.00 WIB. Permainan angklung paglak
Banyuwangi tidak ada batasan durasinya serta tidak ada vokalis dalam pembawaan lagunya. Selain itu ada proses pertukaran peran didalam permainannya. Lagu yang dimainkan disebut sebagai lagu rancagan artinya lagu yang dimainkan tanpa ada reff (pengulangan yang menggunakan bagian lain dari lagu untuk diulang).

Secara umum semua alat musik angklung berbentuk menyerupai tabung. Tabung merupakan salah satu konsep bangun ruang sisi lengkung yang dibahas dalam pembelajaran matematika. Pembahasan tersebut menunjukkan bahwa terdapat konsepkonsep matematika dalam angklung, khususnya angklung paglak. Konsep matematika yang termuat dalam budaya masyarakat secara umum dikenal sebagai Etnomatematika

Menurut Gerdes etnomatematika adalah matematika yang diterapkan oleh kelompok budaya tertentu, kelompok buruh/petani, anak-anak dari masyarakat kelas tertentu, kelas-kelas profesional, dan lain sebagainya. Berbagai budaya yang ada di Indonesia, khususnya angklung paglak Banyuwangi, membuka peluang penelitian eksplorasi yang besar untuk identifikasi konsep-konsep matematika dalam budaya (Tandililing, 2013:193).

Dari segi etimologis, D'Ambrosio mendefinisikan ethnomathematics sebagai praktik matematika yang dilakukan oleh kelompok-kelompok budaya tertentu, seperti masyarakat suku tertentu, kelompok buruh, anakanak dari kelompok usia tertentu, kelas profesional dan sebagainya. Identitas dari kelompok tersebut biasanya bergantung pada fokus minat atau kepentingan, motivasi dan kode-kode tertentu dan jargon yang tidak terkait dengan bidang matematika akademik (Prabawati, 2016:27). 
Salah satu penelitian etnomatematika yang telah dilakukan oleh Putri (2017:30) memberikan kesimpulan bahwa konsep matematika dapat ditemukan pada alat musik yaitu dari segi bentuk (yaitu berwujud bangun lengkung lingkaran, tabung, dan kerucut) maupun teknik permainan (menghitung ketukan). Penelitian lain tentang etnomatematika juga pernah dilakukan oleh Hariastuti (2018:21) memberikan kesimpulan bahwa Secara umum rumah adat Using memiliki komponen dan ornamen yang memuat konsep-konsep geometris. Konsepkonsep geometris yang dapat ditentukan dari komponen rumah adat Using diantaranya adalah (1) konsep bentuk geometris baik dimensi dua maupun dimensi tiga; (2) konsep kesebangunan/kekongruenan;

konsep transformasi geometri, khususnya refleksi; serta (4) konsep geometri fraktal.

Pembahasan

tersebut menunjukkan bahwa angklung paglak merupakan salah satu bagian dari budaya Banyuwangi yang memiliki keunikan dan keistimewaan untuk dieksplorasi dari segi karakteristik dan konsep-konsep matematikanya. Sehingga penelitian ini ditujukan untuk mengidentifikasi karakteristik dan konsep-konsep matematika yang terdapat dalam angklung paglak Banyuwangi.

\section{METODE PENELITIAN}

Penelitian ini menggunakan metode eksploratif-deskriptif yang bertujuan mengidentifikasi karakteristik dan konsep-konsep matematika yang terdapat dalam angklung paglak Banyuwangi. Penelitian ini dimulai dengan penentuan responden. Responden ditentukan dengan metode purposive sampling sehingga diperoleh pembuat angklung paglak (responden 1), pemain musik angklung, (responden 2) dan budayawan Banyuwangi (responden 3). Responden dipilih dengan pertimbangan responden 1 telah membuat angklung paglak lebih dari lima tahun. Responden 2 dipilih dengan pertimbangan sudah pernah terlibat dalam pertunjukan seni musik angklung di kegiatan budaya Banyuwangi minimal sepuluh kali. Responden 3 dipilih dengan pertimbangan budayawan khusus alat musik angklung Banyuwangi.

Teknik pengumpulan data dilakukan dengan metode kajian literatur, observasi, wawancara, dan dokumentasi, yang kemudian dianalisis dan diidentifikasi konsepkonsep matematika yang ada dalam angklung paglak sehingga dapat dilakukan penarikan kesimpulan.

\section{HASIL PENELITIAN DAN PEMBAHASAN}

Penelitian ini dilaksanakan di desa Kemiren dan desa Taman Suruh, Kecamatan Glagah, Kabupaten Banyuwangi dengan pertimbangan diantaranya: responden yang dibutuhkan (pengrajin angklung dan pemain angklung) mayoritas tinggal di desa Kemiren serta masih dapat ditemukan obyek penelitian di desadesa tersebut.

Berdasarkan hasil observasi, dokumentasi dan wawancara pada responden 1, responden 2, dan responden 3 dapat diketahui bahwa angklung paglak merupakan angklung yang dimainkan diatas paglak (gubuk di tengah sawah) dengan 4 sisi cagak (tiang) yang ketinggiannya 3-12 meter di atas tanah. Secara umum paglak memiliki panjang 2 meter dan lebar 1,30 meter. Angklung paglak 
Banyuwangi pertama kali dimainkan di desa Kemiren dan Taman Suruh oleh 4 orang pemain yaitu 2 orang pemain angklung dan 2 orang pemain kendang dengan nada selendro Banyuwangian. Angklung paglak Banyuwangi berfungsi sebagai sarana komunikasi kepada warga ketika ada panen dan sebagai penghusir hama burung yang ada di sawah. Namun juga bisa dimainkan ketika ada penyambutan tamu.

Adapun proses pembuatan angklung paglak Banyuwangi adalah sebagai berikut:

1. Pemilihan bambu

Jenis bambu yang digunakan adalah jenis bambu benel dengan usia bambu sekitar 7 tahunan. Untuk satu set angklung palak yang terdiri dari 15 potong bambu angklung membutuhkan 4-5 batang bambu panjang (lonjoran) tergantung kualitas bambu. Secara umum bambu yang dipotong berdiameter hampir sama sekitar $6 \mathrm{~cm}$ dengan menggunakan konsep persamaan diameter. Bambu dipotong menggunakan golok dengan teknik pemotongannya yang dimulai dari bagian tengah dan dilakukan pada musim panas yaitu kisaran bulan April-Agustus atau disaat bambu tidak sedang bertunas.

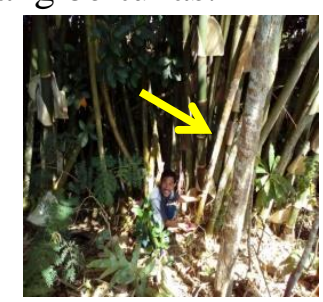

Gambar 2. Pemilihan Bambu Benel

2. Pendiaman Bambu

Pendiaman bambu dilakukan untuk mengurangi kadar air dalam bambu. Pendiaman dilakukan dalam jangka waktu 2 minggu untuk mengurangi kadar air dalam bambu dengan tujuan mendapatkan suara bambu yang tidak sumbang.

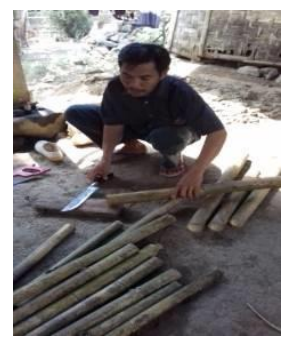

Gambar 3. Pendiaman Bambu

3. Pencucian Bambu

Pencucian bambu dilakukan guna membersihkan bambu dari lumutlumut yang menempel. Pencucian bambu dilakukan di sungai yang mengalir.

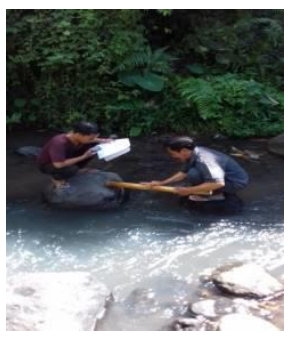

Gambar 4. Pencucian Bambu

4. Pemotongan Bambu

Hal yang perlu dilakukan sebelum pemotongan bambu adalah menyamakan ukuran diameter dan ukuran panjang bambu yang akan dipotong dengan ukuran bambu yang sudah jadi. Namun ketika ukuran yang sudah jadi tidak ada maka cara yang digunakan adalah menggunakan konsep satuan pengukuran tradisional. Konsep satuan pengukuran tradisional merupakan konsep dimana masih menggunakan satuan-satuan tradisional. Dalam hal ini ukuran yang digunakan yaitu sak kilan (jarak antara ujung ibu jari sampai ujung jari kelinking), sak nyengking (jarak antara ujung ibu jari hingga ujung telunjuk), dan satuan jari (diameter jari). 


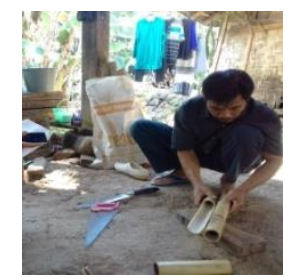

Gambar 5. Pemotongan Bambu

5. Penyerutan Bambu

Bambu yang telah kering diserut hingga berbentuk runcing menggunakan alat seperti pisau yang melengkung dibagian atasnya dan sangat tajam. Setelah diserut bambu terbagi menjadi dua bagian yaitu bumbung (bagian bawah bambu yang sudah diserut) dan januran (bagian atas bambu yang diserut). Ukuran Panjang bumbung dan januran masih menggunakan konsep menyamakan dengan ukuran yang sudah jadi.

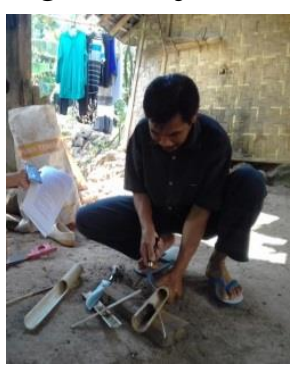

Gambar 6. Penyerutan Bambu

6. Penyeteman Bambu

Penyeteman bambu digunakan untuk menyesuaikan bambu dengan nada selendro Banyuwangian. Penyeteman bambu dilakukan dengan dua cara yaitu dengan cara ditiup dan dipukul.

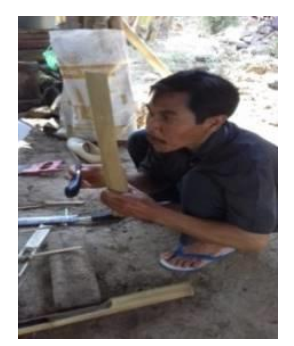

Gambar 7. Penyeteman Bambu dengan Cara Ditiup dan Dipukul
7. Pembuatan Lubang pada Bambu

Sebelum dilakukan proses perakitan angklung. pada bagian punggung bambu yang telah diserut, bagian tengahnya dilubangi. Lubang tersebut berfungsi untuk mengaitkan tali tampar dengan jarak lubang yaitu $\frac{1}{3}$ bagian atas pada januran, serta untuk melihat bumbung.

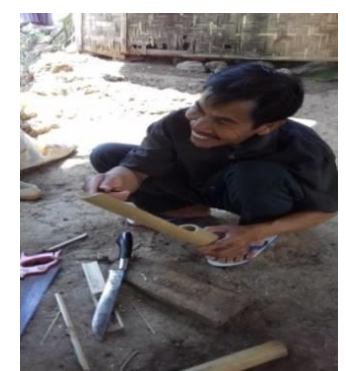

Gambar 8. Melubangi Tabung untuk Tali Tampar

8. Pemukul Angklung

Pemukul angklung dibuat dengan bahan bambu dan kayu. Bambu diserut sampai bentuknya kecil dan memanjang, sedangkan kayu dibentuk seperti lingkaran(dua dimesi) dan tabung (tiga dimensi) dengan diameter $5 \mathrm{~cm}$ supaya lebih mempermudah dalam memukul angklung.
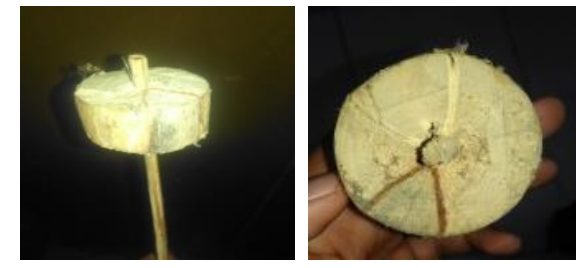

Gambar 9. Pemukul Angklung

9. Percobaan Permainan Angklung

Setelah 15 batang bambu selesai dibuat, batang bambu disusun menjadi satu set angklung dengan tambahan dua pemukul yang terbuat dari bambu yang kemudian dilakukan uji coba permainan oleh pengrajing angklung. 


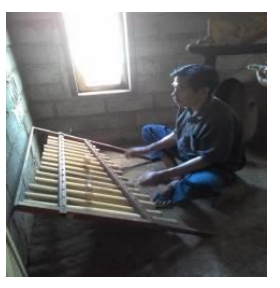

Gambar 10. Uji Coba Angklung

Berdasarkan hasil penelitian yang diperoleh melalui wawancara dan dokumentasi, dapat ditentukan konsepkonsep matematika pada angklung paglak Banyuwangi. Konsep-konsep tersebut diantaranya konsep bentuk geometri baik dua maupun tiga dimensi, konsep satuan pengukuran tradisional, satuan pengukuran penyamaan panjang dan diameter pada angklung, serta proses pertukaran peran (kombinasi).

1) Konsep Geometri

Beberapa bentuk geometris dapat ditemukan pada angklung paglak Banyuwangi yaitu bentuk geometri dimensi dua (bangun datar) dan bentuk geometri dimensi tiga (bangun ruang). Bangun datar yang dapat diidentifikasi adalah bangun persegi panjang, segitiga sama kaki, segitiga siku-siku, trapesium dan lingkaran. Sedangkan bangun ruang yang dapat diidentifikasi adalah bangun tabung, prisma segi empat, prisma segitiga.

A. Bentuk-bentuk Bangun Datar :

1. Bentuk Persegi Panjang pada Paglak

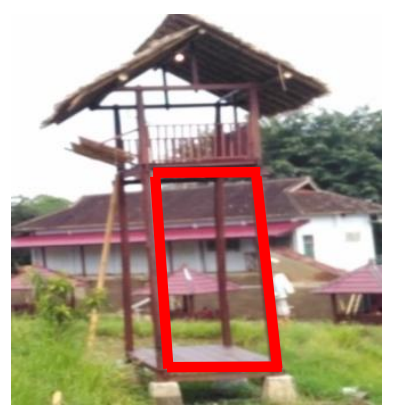

Gambar 11. Bentuk Persegi Panjang pada Paglak
2. Bentuk Segitiga pada Paglak

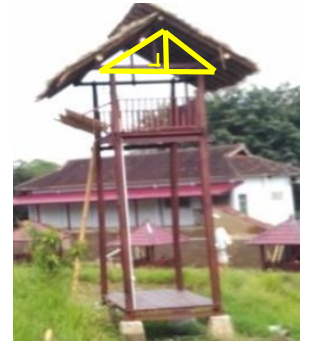

Gambar 12. Bentuk Segitiga Sama Kaki dan Segitiga Siku-siku pada Paglak

3. Bentuk Trapesium pada Angklung

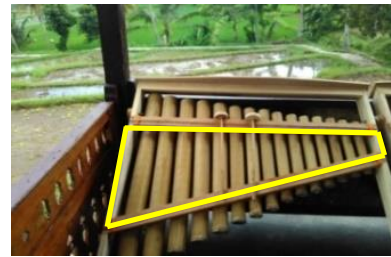

Gambar 13. Bentuk Trapesium pada Angklung

4. Bentuk Lingkaran pada Angklung

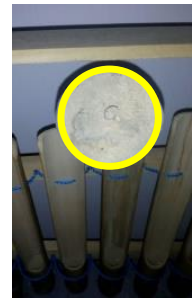

Gambar 14. Bentuk Lingkaran pada Pemukul Angklung

B. Bentuk-bentuk Bangun Ruang :

1. Bentuk Tabung dalam Alat Musik Angklung

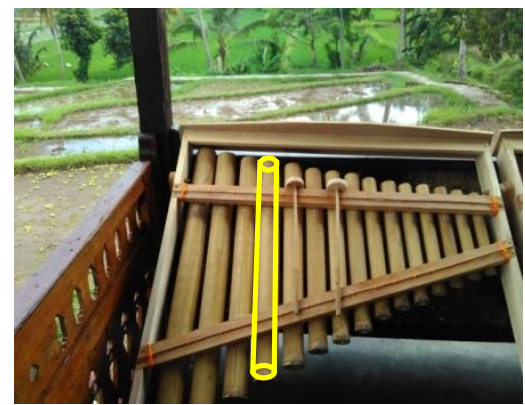

Gambar 15. Bentuk Tabung pada Angklung 
ISSN 2089-8703 (Print) Vol. 7, No. 3 (2018) 380-389

ISSN 2442-5419 (Online)

2. Bentuk Prisma Segi Empat pada Paglak

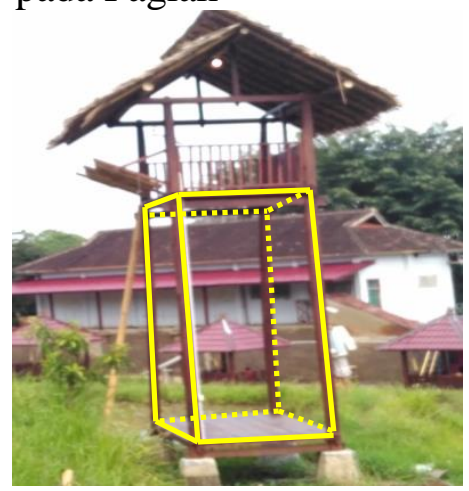

Gambar 16. Bentuk Prisma Segi Empat pada Paglak

3. Bentuk Prisma Segitiga pada Paglak

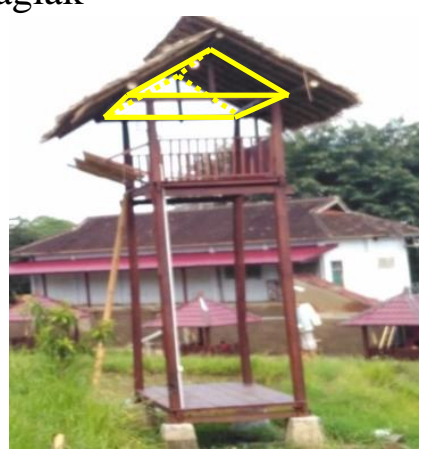

Gambar 17. Bentuk Prisma Segitiga pada Paglak

4. Bentuk Tabung Pada Pemukul Angklung

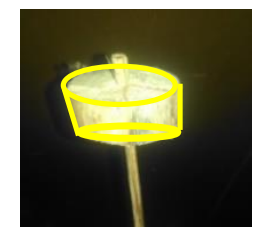

Gambar 18. Bentuk Tabung Pada Pemukul Angklung
2) Keterkaitan Konsep Satuan Pengukuran Tradisional

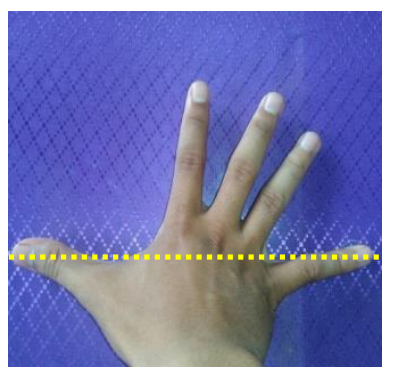

Gambar 19. Satuan Tradisional Sak Killan

Sak kilan tangan orang dewasa jika disetarakan dengan satuan panjang dalam matematika yaitu antara 21- 22 $\mathrm{cm}$.

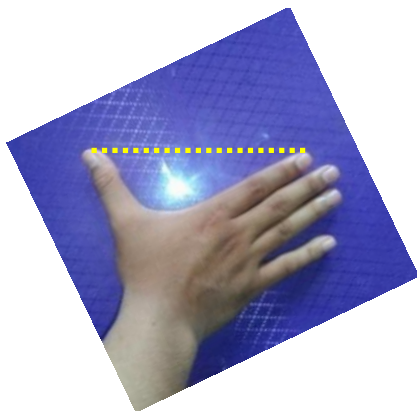

Gambar 20. Satuan Tradisional Sak Nyengking

Sak nyengking tangan orang dewasa jika disetarakan dengan satuan panjang dalam matematika yaitu antara $17-18 \mathrm{~cm}$.

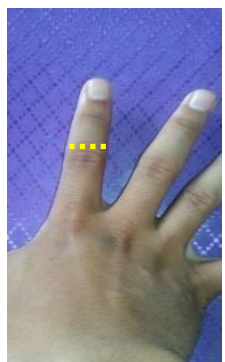

Gambar 21. Satuan Tradisional Sak Jari

Sak Jari tangan orang dewasa jika disetarakan dengan satuan panjang dalam matematika yaitu antara 1-1,5 $\mathrm{cm}$. 
3) Keterkaitan Konsep Kesamaan Ukuran

A. Selain itu pembuatan angklung juga menggunakan konsep menyamakan panjang dan diameter angklung yang akan dibuat dengan obyek yang sudah jadi seperti terlihat pada gambar berikut:

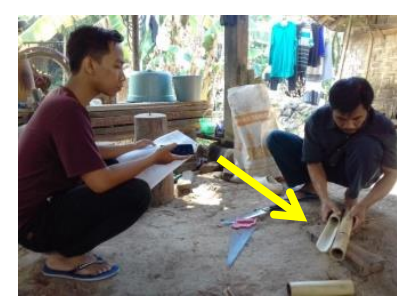

Gambar 22. Proses Pengukuran dengan Cara Menyamakan Obyek dengan Obyek yang Sudah Jadi

B. Bambu yang digunakan dalam membuat satu set angklung membutuhkan 4-5 batang bambu panjang (lonjoran) yang berdiameter mulai dari yang terbesar sekitar $6 \mathrm{~cm}$ sampai yang terkecil sekitar $3 \mathrm{~cm}$ dengan menggunakan satuan penyamaan diameter.

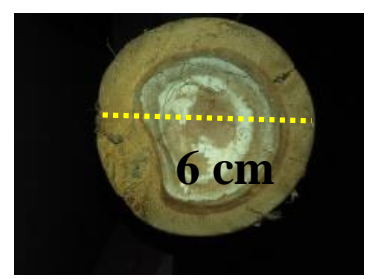

Gambar 23. Proses Pemotongan Bambu Benel Menggunakan Satuan Penyamaan Diameter

C. Ukuran panjang januran dan panjang bumbung mempunyai perbandingan yang sama sekitar 5 : 1. Proses penyerutan bambu pada angklung juga menggunakan konsep menyamakan obyek yang akan dibuat dengan obyek yang sudah jadi dengan kedalaman penyerutan $\frac{1}{2}$ pada diameter angklung. Seperti terlihat pada gambar berikut:

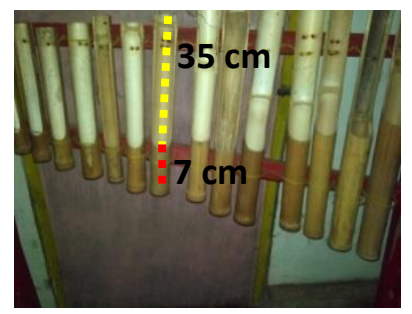

Gambar 24. Perbandingan Panjang antara Januran dengan Bumbung yaitu 5:1

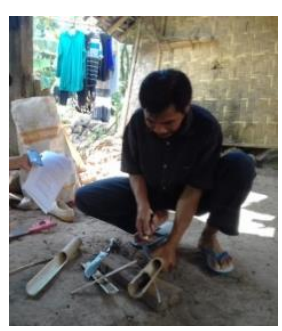

Gambar 25. Proses Penyerutan dengan Menggunakan Konsep

Kesamaan Panjang dengan Obyek yang Sudah Jadi

D. Lubang pada januran berfungsi untuk mengaitkan tali tampar pada penopang angklung paglak yang berjarak hampir sama pada tiap batang angklung yaitu $\frac{1}{3}$ bagian atas pada januran. Dan jarak antara tali tampar bambu satu ke bambu yang lain berjarak sama yaitu $8 \mathrm{~cm}$

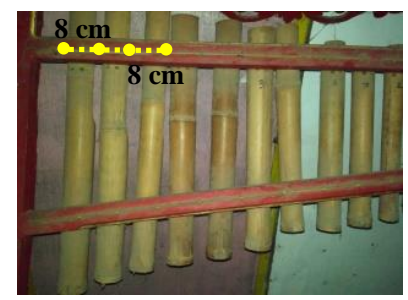

Gambar 26. Melubangi Tabung untuk Tali Tampar 
4) Keterkaitan Terhadap Konsep Kombinasi

Konsep kombinasi merupakan suatu teknik yang menyatakan banyaknya cara dalam menyusun beberapa obyek dari suatu grup tanpa memperhatikan urutan (acak). Kombinasi (pertukaran peran) dalam permainan angklung paglak dilakukan ketika pemain ingin berganti posisi. Pergantian posisi ini dilakukan secara acak (tanpa ada ketentuan khusus). Konsep kombinasi dalam permainan angklung paglak tampak seperti berikut:

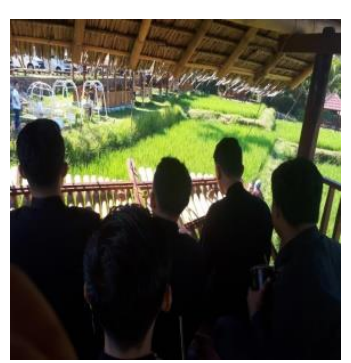

(a) Peran 1

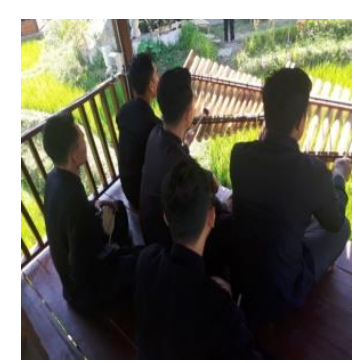

(b)Peran 2
Gambar 27. Proses Pertukaran Peran

Hasil pembahasan diatas dapat diidentifikasi bahwa angklung paglak Banyuwangi memuat konsep- konsep matematika baik dari segi bentuk maupun segi pengukuran. Hal tersebut sesuai dengan penelitian terdahulu yaitu oleh Putri (2017:30) yang menyebutkan bahwa konsep matematika dapat ditemukan pada alat musik.

Implikasi dari hasil penelitian ini untuk kemajuan ilmu pengetahuan yaitu dapat digunakan sebagai rancangan pembelajaran di kelas.

\section{KESIMPULAN DAN SARAN}

Karakteristik angklung paglak Banyuwangi dari segi bentuk dan proses pembuatan sama dengan jenis angklung
Banyuwangi yang lain. Angklung paglak dan angklung Banyuwangi yang lain memiliki perbedaan dari segi banyak pemain. Pemain angklung paglak sebanyak 4 orang yaitu 2 orang pemain angklung dan 2 orang pemain kendang sedangkan pemain angklung Banyuwangi yang lain beragam.

Konsep-konsep matematika yang dapat ditentukan dari angklung paglak Banyuwangi diantaranya adalah: (1) konsep bentuk geometris dua maupun tiga dimensi yaitu bangun datar seperti persegi panjang, segitiga sama kaki, segitiga siku-siku, trapesium, lingkaran, dan bangun ruang seperti tabung, prisma segi empat, prisma segitiga; (2) konsep satuan pengukuran tradisional; (3) konsep kesamaan ukuran dan (4) konsep kombinasi.

Sebagai pengembangan lebih lanjut, dapat digunakan untuk mengembangkan rancangan pembelajaran. Indenftifikasi konsep etnomatematika pada budaya dan alat musik Banyuwangi yang lain.

\section{DAFTAR PUSTAKA}

Hariastuti, R. M. (2018). Kajian Konsep-Konsep Geometris Dalam Rumah Adat Using Banyuwangi Sebagai Dasar Pengembangan Pembelajaran Kontekstual Berbasis Etnomatematika. AKSIOMA Jurnal Pendidikan Matematika, Volume 7 Nomor 1, 13-21.

Komariyah, L. (2016). Pengaruh Musik Angklung Terhadap Kualitas Hidup Wanita Lanjut Usia. Jurnal Pendidikan Keperawatan Indonesia Vol.2 No. 1 , 10-15.

Prabawati, M. N. (2016). Etnomatematika Masyarakat Pengrajin Rajapoah Kabupaten Tasikmalaya. Jurnal Ilmiah Program Studi Matematika 
STKIP Siliwangi, Vol 5, No. 1, 25-31.

Putri, L. I. (2017). Eksplorassi Etnomatematika Kesenian Rebana Sebagai Sumber Belajar Matematika pada Jenjang MI. Jurnal Ilmiah "PENDIDIKAN DASAR” Vol. IV No. 1, 21-31.

Rohmatun, Y., Julia, \& Jayadinata, A. K. (2017). Meningkatkan Apresiasi Seni Musik Siswa Kelas V pada Mata Pelajaran Seni Budaya dan Keterampilan Melalui Media Alat Musik Angklung. Jurnal Pena Ilmiah: Vol. 2 No 1, 531-540.

Suharti, M. (2012). Tari Gandrung Sebagai Obyek Wisata Andalan Banyuwangi. HARMONIA, Volume 12, No.1 , 24-31.

Sutarto, A. (2006). Sekilas Tentang Masyarakat Using. Pembekalan Jelajah Budaya 2006, Balai Kajian Sejarah dan Nilai Tradisional Yogyakarta, pp. 113.

Syaiful, M. (2015). Angklung Paglak dan Nilai-nilai Kehidupan Masyarakat Desa. In S. Anasrullah, Jagat Osing; Seni, Tradisi, \& Kearifan Lokal Osing (pp. 35-50). Banyuwangi: Rumah Budaya Osing-Lembaga Masyarakat Adat Osing.

Tandililing, E. (2013). Pengembangan Pembelajaran Matematika Sekolah dengan Pendekatan Etnomatematika Berbasis Budaya Lokal Sebagai Upaya untuk Meningkatkan Kualitas Pembelajaran Matematika di Sekolah. Seminar Nasional Matematika dan Pendidikan Matematika (pp. MP 193 -MP 202). Yogyakarta: Jurusan

\author{
Pendidikan Matematika, \\ FMIPA, UNY.
}

Tedjasendjaja, G. A., \& Dharmadi, S. (2015). Kajian Pelestarian Alat Musik Angklung Dalam Bentuk Kampanye Sosial. Jurnal RupaRupa Vol. 4, No. 2, 109-117. 